The Canadian Mineralogist

Vol. 41, pp. 1397-1412 (2003)

\title{
TWO STAGES OF "METAMORPHIC VERMICULITE" GROWTH IN SCHISTS FROM THE MALÁGUIDE COMPLEX, BETIC CORDILLERA, SPAIN
}

\author{
María Dolores RUIZ CRUZ ${ }^{\S}$ \\ Departamento de Química Inorgánica, Cristalografía y Mineralogía. Facultad de Ciencias, Campus de Teatinos, \\ E-29071 Málaga, Spain
}

\begin{abstract}
Two texturally different types of "metamorphic vermiculite" were identified in EMPA and TEM-AEM investigations of schist samples from the deepest Paleozoic rocks of the Maláguide Complex, Betic Cordillera, Spain. The two generations of "vermiculite" formed during late stages of Alpine metamorphism. The first generation occurs as grains parallel to the main schistosity, whereas the second one appears as a pseudomorph after garnet. The EMPA data reveal lower $\mathrm{Al}_{2} \mathrm{O}_{3}$ and $\mathrm{MgO}$ contents for the first generation, whereas the "vermiculite" pseudomorph after garnet shows a lower $\mathrm{CaO}+\mathrm{K}_{2} \mathrm{O}+\mathrm{Na}_{2} \mathrm{O}$ content. On the other hand, EMPA FeO and $\mathrm{TiO}_{2}$ data are not discriminants because submicrometric inclusions of $\mathrm{Fe}$ and $\mathrm{Fe}-\mathrm{Ti}$ oxides affect the composition of the first generation of "vermiculite". A more accurate structural and chemical differentiation between the two generations of "vermiculite" was obtained by TEM-AEM analyses. The first generation of "vermiculite" grains is characterized by interstratifications of layers 10 and $14 \AA$ thick, belonging to vermiculite (A) and chlorite (B), respectively. Regular sequences 24 and $34 \AA$ thick, corresponding to A + B and 2A + B sequences, also are present. These grains appear locally retrograded to kaolinite and Fe oxide. The second generation of "vermiculite" pseudomorphic after garnet consists of more complex chlorite, muscovite, and vermiculite intergrowths, with isolated packets about 1000 A thick of an aluminous smectite. The $\mathrm{Fe} /(\mathrm{Fe}+\mathrm{Mg})$ value, based on AEM analyses, clearly distinguish between the first and second generations; average values of 0.39 and 0.55 are obtained, respectively. The first generation of "vermiculite" belongs to the synkinematic main stage of mineral growth during the Alpine metamorphic event. The association of metamorphic minerals (garnet, andalusite and staurolite) suggests temperatures of about $500^{\circ} \mathrm{C}$ and relatively low pressures. The metamorphic retrogression favored the destabilization of garnet, probably producing the aluminous smectite, which evolved toward the second generation of "vermiculite" grains, chlorite, and muscovite. Temperatures below $400^{\circ} \mathrm{C}$ are estimated for this late-stage thermal event.
\end{abstract}

Keywords: TEM-AEM data, "metamorphic vermiculite", mixed-layer silicates, chlorite, muscovite, smectite, Maláguide Complex, Betic Cordillera, Spain.

\section{SOMMAIRE}

Deux types de "vermiculite métamorphique", distincts dans leur développement textural, ont été identifiés au cours d'une étude d'échantillons de schistes paléozoïques provenant des parties profondes du complexe de Maláguide, Cordillère Bétique, en Espagne. Les deux générations de "vermiculite"se sont formées lors des stades ultimes du métamorphisme alpin. Les grains de la première génération sont disposés parallèlement à la schistosité, tandis que la seconde variété remplace le grenat. Les données de microsonde électronique révèlent un niveau de $\mathrm{Al}_{2} \mathrm{O}_{3}$ et de $\mathrm{MgO}$ plus faible pour la première génération, tandis que la "vermiculite" qui remplace le grenat accuse une teneur plus faible en $\mathrm{CaO}+\mathrm{K}_{2} \mathrm{O}+\mathrm{Na}_{2} \mathrm{O}$. Les niveaux de $\mathrm{FeO}$ and $\mathrm{TiO}_{2}$, tels qu'obtenus par microsonde, ne permettent pas une discrimination à cause d'inclusions submicrométriques d'oxydes de $\mathrm{Fe}$ et $\mathrm{Fe}-$ Ti dans la première génération de "vermiculite". Des données plus justes permettant une différenciation structurale et chimique ont été obtenues par microscopie électronique par transmission avec sonde analytique (dispersion d'énergie). Les grains de la première génération de "vermiculite" contiennent des interstratifications de couches d'une épaisseur de 10 et $14 \AA$ A , typiques de la vermiculite (A) et de la chlorite (B), respectivement. Des séquences régulières d'une épaisseur de 24 et $34 \AA$ A en épaisseur correspondraient à des séquences $\mathrm{A}+\mathrm{B}$ et $2 \mathrm{~A}+\mathrm{B}$. Ces grains semblent affectés localement par une rétrogression à la kaolinite et à un oxyde de fer. La seconde génération, pseudomorphique par rapport au grenat, contient un assemblage plus complexe de chlorite, muscovite, et vermiculite en intercroissance, avec des paquets isolés d'une smectite alumineuse environ $1000 \AA$ en épaisseur. $\mathrm{La}$ valeur $\mathrm{Fe} /(\mathrm{Fe}+\mathrm{Mg})$ fondée sur les mesures $\mathrm{AEM}$ permettent de distinguer clairement la première et la deuxième génération; des valeurs moyennes de 0.39 et 0.55 en résultent. La première génération de "vermiculite" fait partie du stade syncinématique principal de croissance minérale lors du métamorphisme alpin. L'association de minéraux métamorphiques (grenat,

$\S \quad$ E-mail address: mdruiz@uma.es 
andalusite et staurolite) semble indiquer une température d'environ $500^{\circ} \mathrm{C}$ et une pression relativement faible. La rétrogression métamorphique a favorisé la déstabilisation du grenat, menant probablement à la formation d'une smectite alumineuse, qui a évolué en "vermiculite" de deuxième génération, en chlorite, et en muscovite. Un intervalle de température inférieur à $400^{\circ} \mathrm{C}$ semble indiqué pour ce stade tardif de l'événement thermique.

(Traduit par la Rédaction)

Mots-clés: données TEM-AEM, "vermiculite métamorphique", silicates interstratifiés, chlorite, muscovite, smectite, complexe Maláguide, Cordillère Bétique, Espagne.

\section{INTRODUCTION}

High-temperature or metamorphic vermiculite, as defined by Velde (1978), is a common constituent of Paleozoic rocks of the Maláguide Complex, in the Betic Cordillera of Spain (Ruiz Cruz 1999, 2001). Metamorphic vermiculite includes, however, a variety of structures, as previously noted by other authors (e.g., Francescelli et al. 1986, Beaufort 1987, Mellini et al. 1991). As a result, the more appropriate terms "vermiculitic phases" or "vermiculite" will be used in this work to designate the phases showing optical and chemical properties like metamorphic vermiculite. These phases generally consist of semirandom 1:2 mica-chlorite and 1:1 chlorite-vermiculite mixed-layers. The 1:2 mica-chlorite mixed-layers are present in graywackes and shales from the upper Paleozoic rocks (Ruiz Cruz 2001), trending toward ordered 1:1 chloritevermiculite mixed-layers, vermiculite, and biotite as metamorphic conditions increase (Ruiz Cruz 1999). Mica-chlorite mixed-layers coexist with muscovite and abundant chlorite, whereas intergrowths of chloritevermiculite mixed-layers, vermiculite and biotite coexist with muscovite, minor chlorite, and occasionally with paragonite, chloritoid, andalusite, staurolite and garnet (Ruiz Cruz \& Rodríguez Jiménez 2002).

The vermiculitic phases have been previously interpreted to have formed from chlorite, either during weathering or retrograde metamorphism (e.g., Johnson 1964, Brown 1967, Proust 1982, Proust et al. 1986, Banfield \& Murakami 1988, Murakami et al. 1996), or during prograde metamorphism (e.g., Kerrick \& Cotton 1971, Velde 1978, Maresch et al. 1985). In the Maláguide rocks, textural, chemical and structural evolution with increasing metamorphic conditions indicate that most of these phases formed during prograde Alpine metamorphism (Ruiz Cruz 1999, 2001). Nevertheless, some garnet-bearing schists show two texturally different types of "vermiculite", one parallel to the main schistosity, the second one present as a pseudomorph after garnet, suggesting two stages of "vermiculite" growth. In the present work, I describe the two types of "vermiculite", and compare their chemical and structural differences.

\section{OCCURREnCe ANd Petrography}

The Maláguide Complex is a part of the Internal zones of the Betic Cordillera. It contains sedimentary units from Paleozoic to early Miocene ages (Mäkel 1985), showing a complete diagenetic-metamorphic sequence, and the transition from early diagenesis to epizone conditions (Ruiz Cruz \& Rodríguez Jiménez 2002). The metamorphic evolution of the Maláguide Complex includes a Hercynian episode, followed by the Alpine one (Mäkel 1985, Ruiz Cruz 1997). The Ordovician-Silurian units show a well-developed $\mathrm{S}_{1}$ schistosity parallel to the lithological contacts. This schistosity is marked by the preferred orientation of white mica, chlorite, "vermiculite" and, occasionally, andalusite. A later $\mathrm{S}_{2}$ crenulation cleavage is also evident, but in most cases, it is hidden by late growth of minerals. In the area studied, located near Málaga, at the limit between the Maláguide and Alpujárride complexes (Fig. 1), there is no evidence of the Alpine high-pressure event, which has been well documented in other terranes of the Internal Zones of the Betic Cordillera (e.g., Azañón 1994, Balanyá et al. 1997, Azañón et al. 1998, Puga et al. 2000, 2002).

The vermiculitic phases were identified in the study area throughout the Paleozoic sequence. In most of these rocks, only one stage of "vermiculite" growth was identified; it follows the $S_{1}$ schistosity (Ruiz Cruz 1999). The oldest Ordovician-Silurian rocks show, however, metamorphic assemblages characterized occasionally by the presence of garnet. Garnet is either unaltered or partially retrograded to $\mathrm{Fe}$ oxides, this being the only feature revealing retrogression. Nevertheless, some samples of schists show, in addition, "vermiculite" pseudomorphic after garnet. For this study, samples were selected from these deepest rocks, containing partly altered garnet.

The Ordovician-Silurian rocks are cut by a dense dyke-swarm, characterized by greenschist to lower amphibolite metamorphic facies. This metamorphism, related to a very late episode of extension (Ruiz Cruz \& Novak 2003, Ruiz Cruz et al. 2003), is characterized by the growth of vermiculitic phases together with the metamorphic assemblages in the dyke rocks. In the study area, the temperatures deduced from the metamorphic assemblage in dykes are of the order of $300-350^{\circ} \mathrm{C}$ (Ruiz Cruz et al. 2003). 
The first population of vermiculitic phases appears as grains from 0.05 to $0.2 \mathrm{~mm}$ thick, roughly parallel to the $S_{1}$ schistosity (Fig. 2A). This schistosity is typically marked by the preferred orientation of muscovite, vermiculite and andalusite, which are the main synkinematic phases. The grains of garnet are not deformed by the $S_{1}$ schistosity, suggesting that garnet growth was syn- or postkinematic. Optically, "vermiculite" grains show a well-marked yellow to dark brown pleochroism, and second-order birefringence colors. Chlorite was not identified optically in the matrix of the rock.

"Vermiculite" pseudomorphs after garnet show, on the contrary, a random orientation, a lighter color and a lower pleochroism than "vermiculite" from the matrix. In these areas, grains with the optical characteristics of chlorite, with different degree of transformation into "vermiculite", also are observed (Fig. 1B). Similar tex- tures were described by Maresch et al. (1985) in chlorite pseudomorphs after garnet from metabasic rocks.

\section{Analytical Procedures}

Numerous samples of garnet-bearing schist were studied by electron-microprobe analysis (EMPA) and $\mathrm{X}$-ray diffraction (XRD). One of these samples was selected for the study by transmission-analytical electron microscopy (TEM-AEM).

XRD patterns were recorded using a Siemens D5000 diffractometer with $\mathrm{Cu} K \alpha$ radiation and a graphite monochromator, operated at $35 \mathrm{~mA}$ and $40 \mathrm{kV}$, with a step size of $0.01^{\circ}$ and a counting time of $1 \mathrm{~s}$. Powders of the whole rocks were used to determine the mineralogical composition, whereas oriented samples of the $<20 \mu \mathrm{m}$ size-fractions, in the air-dried state (natural and

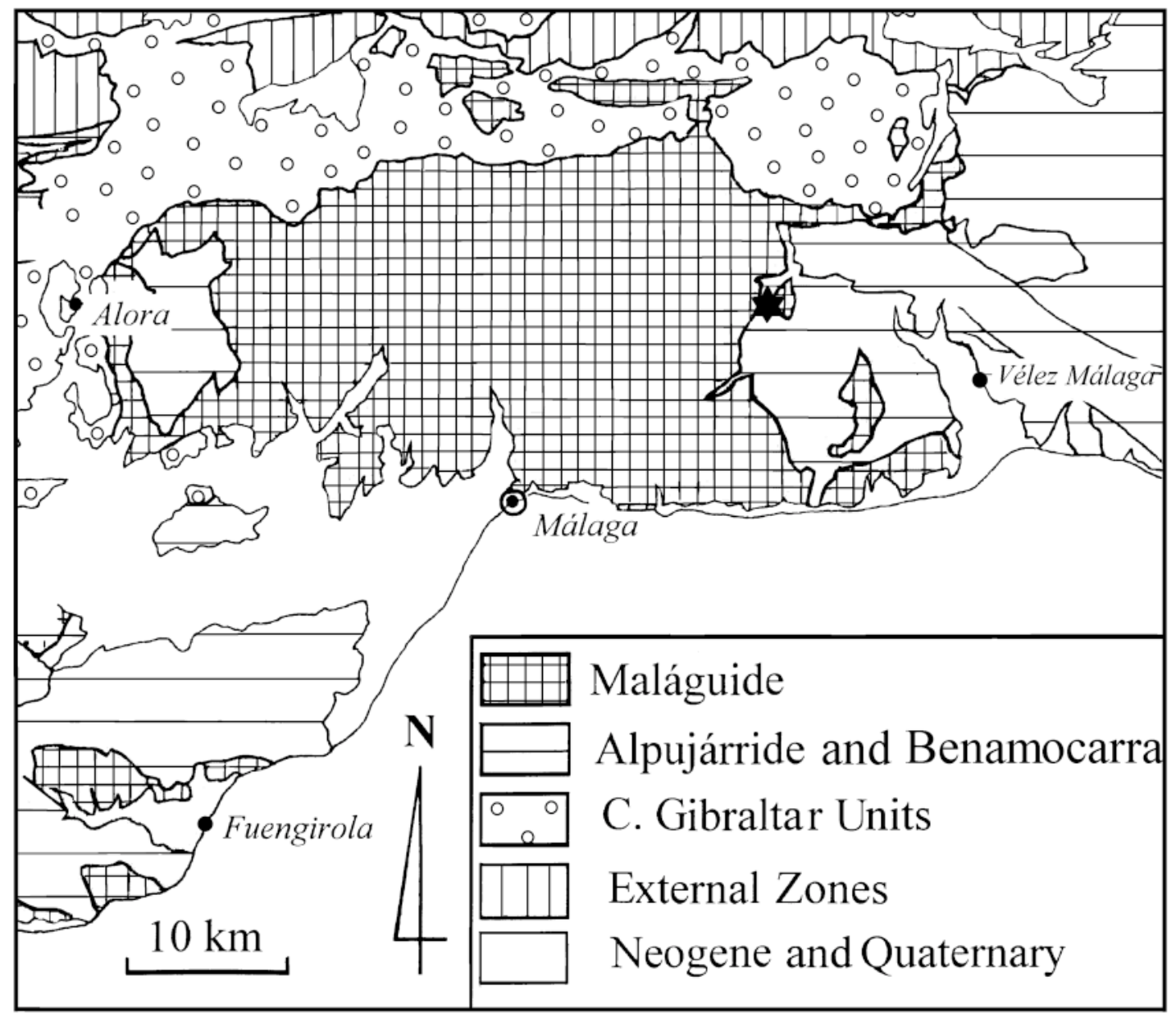

FIG. 1. Tectonic sketch-map of the study area and position (star) of the sample selected for the TEM-AEM study. 
Mg-saturated), and both after ethylene glycol solvation and heating at $550^{\circ} \mathrm{C}$, were used for phyllosilicate identification.

EMPA analyses were performed using a Cameca SX-50 microprobe; acceleration voltage was $20 \mathrm{kV}$, the beam current was $20 \mathrm{nA}$, and the spot size was set to 5 $\mu \mathrm{m}$. Wollastonite $(\mathrm{Si}, \mathrm{Ca})$, synthetic $\mathrm{Al}_{2} \mathrm{O}_{3}(\mathrm{Al})$, orthoclase $(\mathrm{K})$, albite $(\mathrm{Na})$, synthetic $\mathrm{Fe}_{2} \mathrm{O}_{3}(\mathrm{Fe})$, periclase $(\mathrm{Mg})$ and synthetic $\mathrm{MnTiO}_{3}(\mathrm{Mn}, \mathrm{Ti})$ were used as standards. Under routine operating conditions, accuracy is about $1.5 \%$ of the measured concentrations.

Petrographic thin sections cut perpendicularly to the $S_{1}$ schistosity were used to prepare TEM-AEM samples. The phyllosilicate grains were selected from both ma- trix and garnet porphyroblasts. Samples were ionthinned and carbon-coated, and examined both using a $200 \mathrm{kV}$ JEOL $2000 \mathrm{FX}$ microscope, coupled with a Kevex Quantum X-ray energy-dispersion spectroscopic system (Universidad Complutense), and a Philips CM20 transmission electron microscope, equipped with an EDAX solid-state EDX detector (Universidad de Granada). Muscovite, albite, spessartine, forsterite and titanite were used as standards to calculate K-factors by the thin-film method of Lorimer \& Cliff (1976). Under routine operating conditions, accuracy is about $3 \%$ of the measured concentrations for all elements except for the lighter ones $(\sim 8 \%)$.
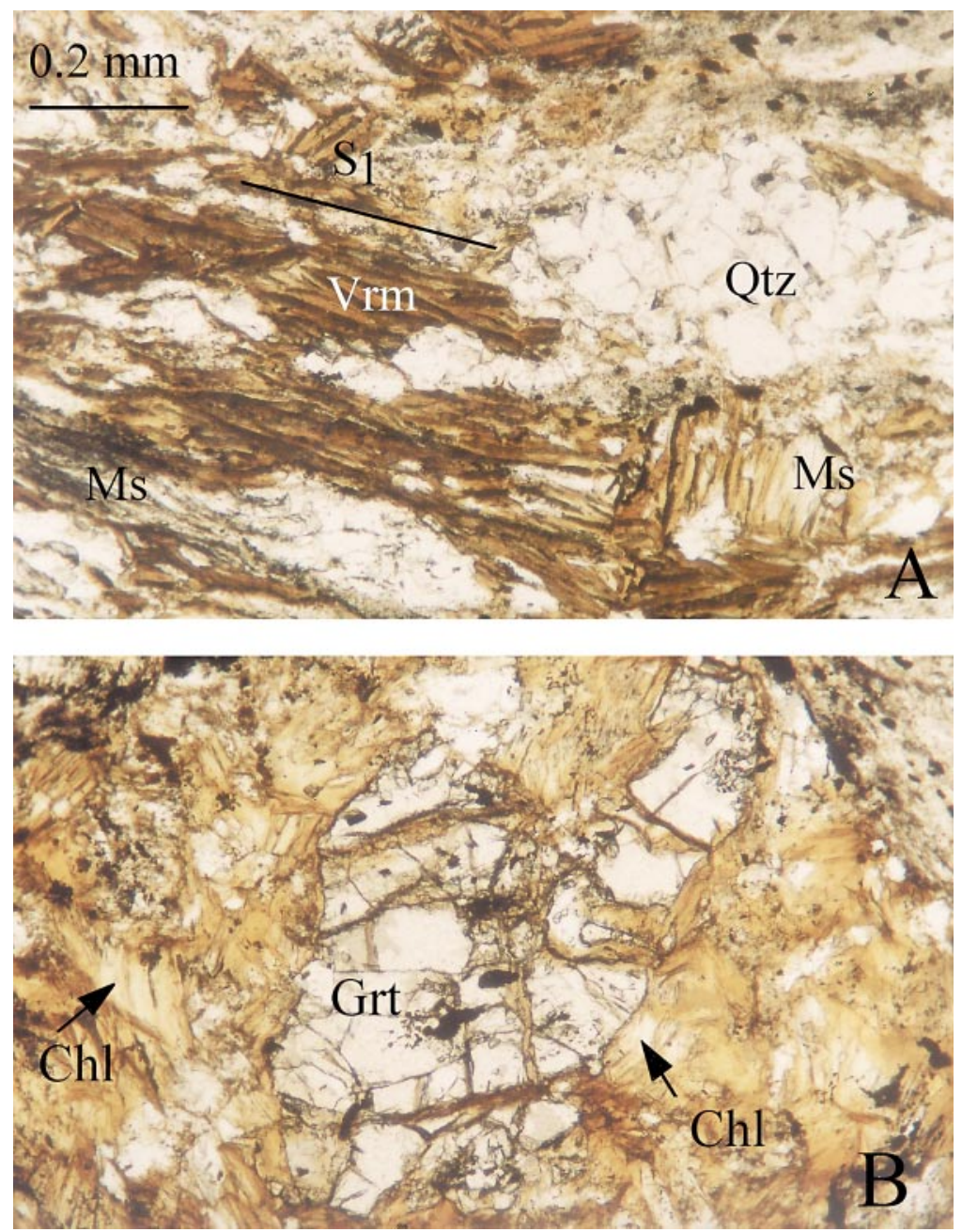

FIG. 2. Typical aspect of "vermiculite" from the matrix (A) and of "vermiculite" pseudomorph after garnet (B), both in plane light. Arrows in B mark chlorite grains partially transformed into vermiculite. Ms: muscovite. 


\section{RESUlts}

\section{X-ray-diffraction study}

The XRD patterns of the sample selected for the TEM-AEM study are shown in Figure 3. The air-dried pattern shows "vermiculite" reflections at $\sim 14.1, \sim 7.2$ and $3.54 \AA$, together with reflections attributed to mica (at 10 and $5 \AA$ ), quartz and albite. Vermiculitic phases are easily distinguishable from chlorite in the XRD pat-

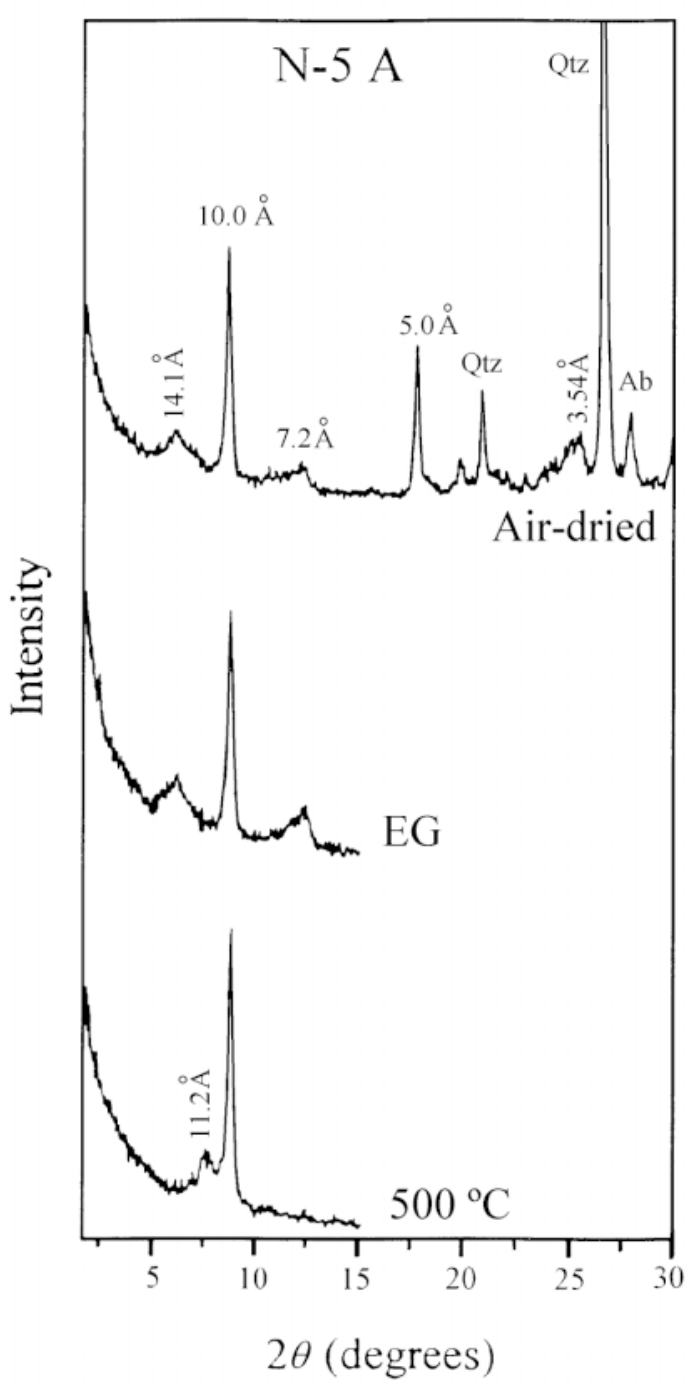

FIG. 3. X-ray-diffraction patterns $\left(0-30^{\circ} 2 \theta\right.$ range $)$ of the $<20$ $\mu \mathrm{m}$ size-fraction of the sample studied, obtained from oriented preparations, in the natural state (air-dried), after treatment with ethylene glycol (EG) and after heating at $500^{\circ} \mathrm{C}$. Qtz: quartz. Ab: albite. terns because of the $7 \AA$ : $14 \AA$ intensity ratio, which is very high in the case of chlorite and lower than 1 in the case of "vermiculitic phases" (Bailey 1980, Ruiz Cruz 1999).

Neither the position nor the intensity of the "vermiculite" reflections is affected by ethylene glycol. On the contrary, heating to $500^{\circ} \mathrm{C}$ leads to a shift of the 14.1 $\AA$ reflection to $11.2 \AA$, whereas the 10 - $\AA$ reflection increases slightly in intensity. This behavior points out the presence of randomly ordered vermiculite-rich chloritevermiculite mixed-layers, together with discrete vermiculite (Brown \& Brindley 1980, Reynolds 1988). Nevertheless, since the sample contains the two types of "vermiculite", the XRD patterns do not permit a differentiation between the two populations of "vermiculite".

\section{Electron-microprobe study}

EMPA data on the garnet indicate that it is compositionally homogeneous, the almandine component being dominant, with $\mathrm{Ca}$ content of the order of 0.50 atoms per formula unit (apfu of 12 atoms of oxygen), and $\mathrm{Mn}$ content, $<0.10$ apfu.

About eighty grains of the two texturally different types of "vermiculite" were analyzed. The back-scattered images of pseudomorphs of "vermiculite" after garnet show very variable contrast, indicating changes in composition within single grains, both parallel and transverse to the cleavage (Fig. 4A). Dark areas show compositions compatible with muscovite, whereas light areas show compositions in agreement with intergrowths of "vermiculite" and chlorite. These intergrowths, although present, are generally sparser and better defined in "vermiculite" grains parallel to the schistosity (Fig. 4B). The EMPA data presented in Table 1 were obtained from areas with homogeneous dark contrast. Nevertheless, some contamination by muscovite is evident, as revealed by anomalously high $\mathrm{SiO}_{2}$ and $\mathrm{K}_{2} \mathrm{O}$ contents.

As is visible in Figure 5, "vermiculite" grains forming part of $S_{1}$ and those that replace garnet show some chemical differences. The $\mathrm{SiO}_{2}$ contents are within a narrower interval (26.5-30.8 wt.\%) for "vermiculite" belonging to $S_{1}$ than in "vermiculite" pseudomorphs after garnet (25.5-33.0 wt.\%). According to the $\mathrm{SiO}_{2}$ contents, some "vermiculite" compositions from the second population can be considered to correspond to chlorite. Both populations of "vermiculite" show a clear positive correlation between $\mathrm{SiO}_{2}$ and $\mathrm{K}_{2} \mathrm{O}$ and between $\mathrm{SiO}_{2}$ and the sum $\mathrm{CaO}+\mathrm{Na}_{2} \mathrm{O}+\mathrm{K}_{2} \mathrm{O}$ (Figs. 5A, B). Both plots reveal that "vermiculite" following the schistosity contains higher potassium and alkali + Ca than "vermiculite" from garnet replacements. The sum $\mathrm{CaO}$ $+\mathrm{Na}_{2} \mathrm{O}+\mathrm{K}_{2} \mathrm{O}$ is $<0.5$ wt. \% in some grains of "vermiculite" pseudomorphs; these grains also show the lowest $\mathrm{SiO}_{2}$ contents, indicating large amounts of intergrown chlorite. On the contrary, the sum is $>1 \mathrm{wt} . \%$ 
in all the analyzed grains of "vermiculite" parallel to the schistosity, indicating the lack of discrete grains of chlorite. The plots in Figures 5C and 5D also allow one to distinguish between the two populations of "vermiculite" based on the $\mathrm{Mg}$ and $\mathrm{Al}$ contents, which are generally higher in the second group. Additional information can be obtained from the total oxide versus $\mathrm{Al}_{2} \mathrm{O}_{3}$ plot (Fig. 5D). The oxide total is systematically lower in "vermiculite" parallel to the schistosity (77.5-85.3) than in "vermiculite" pseudomorphs (82.2-88.7), these lat-

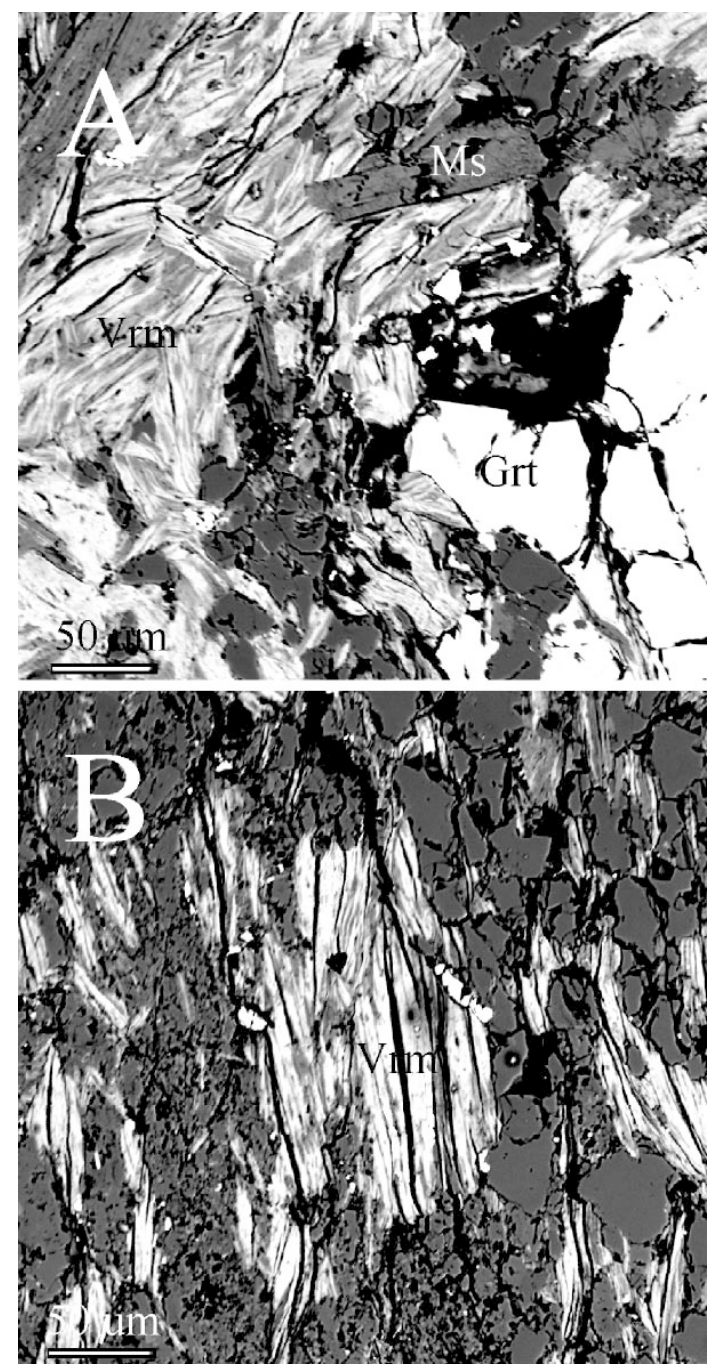

FIG. 4. BSE images of "vermiculite". A. Randomly oriented "vermiculite" pseudomorphs after garnet show irregular areas with different contrast, indicating changes in composition. B. "Vermiculite" following the $S_{1}$ schistosity show scarcer dark, muscovite-like areas within the "vermiculite" grains. Vrm: "vermiculite”, Ms: muscovite, Grt: garnet. ter values probably indicating contamination by muscovite.

Both BSE images and anomalous higher $\mathrm{Fe}$ and $\mathrm{Ti}$ signals reveal the presence of different micrometric to submicrometric grains of $\mathrm{Fe}$ and $\mathrm{Fe}-\mathrm{Ti}$ oxides within "vermiculite" from the matrix. Because of the dimensions of the electron beam (see above), it was not possible to avoid a contamination of the phyllosilicate analyses from oxide signals. Therefore, the EMPA data do not discriminate the two "vermiculite" populations on the basis of $\mathrm{FeO}$ and $\mathrm{TiO}_{2}$ contents.

\section{Transmission-analytical microscopy study}

TEM investigations of "vermiculite" grains belonging to the main schistosity reveal the presence of packets $(0.2-0.5 \mu \mathrm{m}$ thick) showing both a mottled aspect and lenticular gaps, characteristic of "vermiculite" (Ruiz Cruz 1999). Lattice-fringe images (Fig. 6) are mainly characterized by layers 10 and $14 \AA$ thick, belonging to vermiculite (A), and chlorite (B), respectively. Ordered sequences of vermiculite and chlorite layers commonly give rise to interstratifications characterized by regular sequences $24 \AA$ (Fig. 7A) and $34 \AA$ (Fig. 7B) thick, corresponding to $\mathrm{A}+\mathrm{B}$ and $2 \mathrm{~A}+\mathrm{B}$. Sequences with a periodicity of $38 \AA$, corresponding to two chlorite layers plus one vermiculite layer $(A+2 B)$, also are common in "vermiculitic phases" (Maresch et al. 1985, Ruiz Cruz 2001), but were not observed in this study. The ordered 1:1 sequence $(\mathrm{A}+\mathrm{B})$ leads to a SAED pattern with regular $24-\AA$ periodicity (Fig. 7A, inset), whereas the higher-order sequence $(2 \mathrm{~A}+\mathrm{B})$ gives a more disordered SAED pattern in which the $34-\AA$ periodicity is observable (Fig. 7B, inset).

Some "vermiculite" packets show an evident alteration to kaolinite and $\mathrm{Fe}$ oxide. Alteration to kaolinite occurs both along and across the "vermiculite" packets (Fig. 8A); commonly, in association with this phase, there is a low-crystallinity $\mathrm{Fe}$ oxide (presence of rings instead of spots in the SAED inset of Fig. 8B), forming irregular lenses within the "vermiculite" packets (Fig. 8B).

Besides the Fe-oxide inclusions, "vermiculite" grains contain also numerous inhomogeneously distributed and randomly oriented inclusions of Fe-Ti oxides (probably ilmenite), from 2 to $10 \mu \mathrm{m}$ in length and 0.5 $2 \mu \mathrm{m}$ in thickness (Fig. 9). These inclusions, also common in muscovite grains, are present as elongate grains, both parallel and perpendicular to the (001) planes of the phyllosilicate, Both the irregular distribution and the different orientations observed indicate that these are primary inclusions.

In Table 2, some AEM data for "vermiculite" grains belonging the main schistosity are presented. In spite of the chemical inhomogeneities related to the different ratios of $\mathrm{A}$ and $\mathrm{B}$ component layers, all the structural formulae have been calculated on the basis of $14(\mathrm{O}, \mathrm{OH})$ to facilitate comparisons. These data reveal that the 
METAMORPHIC VERMICULITE, MALÁGUIDE COMPLEX, BETIC CORDILLERA

TABLE 1. REPRESENTATIVE EMPA DATA ON "VERMICULITE" FROM THE MATRIX AND THAT PSEUDOMORPHIC AFTER GARNET, MALÁGUIDE COMPLEX, SPAIN

\begin{tabular}{|c|c|c|c|c|c|c|c|c|c|c|c|c|c|}
\hline & \multicolumn{6}{|c|}{ Vermiculite parallel to the schistosity } & \multicolumn{7}{|c|}{ Vermiculite pseudomorphs after garnet } \\
\hline & 1 & 2 & 3 & 4 & 5 & 6 & 1 & 2 & 3 & 4 & 5 & 6 & 7 \\
\hline $\begin{array}{l}\mathrm{SiO}_{2} \text { wt.\% } \\
\mathrm{Al}_{2} \mathrm{O}_{3} \\
\mathrm{TiO}_{2} \\
\mathrm{Cr}_{2} \mathrm{O}_{3} \\
\mathrm{FeO} \\
\mathrm{NiO} \\
\mathrm{MgO} \\
\mathrm{MnO} \\
\mathrm{CaO} \\
\mathrm{Na}_{2} \mathrm{O} \\
\mathrm{K}_{2} \mathrm{O}\end{array}$ & $\begin{array}{r}26.10 \\
18.74 \\
4.93 \\
0.00 \\
25.62 \\
0.00 \\
8.63 \\
0.11 \\
0.18 \\
0.03 \\
0.95\end{array}$ & $\begin{array}{r}27.16 \\
17.75 \\
0.48 \\
0.01 \\
26.28 \\
0.03 \\
8.22 \\
0.03 \\
0.40 \\
0.11 \\
0.81\end{array}$ & $\begin{array}{r}28.14 \\
18.01 \\
0.13 \\
0.01 \\
25.95 \\
0.05 \\
7.41 \\
0.00 \\
0.45 \\
0.17 \\
1.71\end{array}$ & $\begin{array}{r}29.07 \\
18.72 \\
0.08 \\
0.05 \\
25.81 \\
0.02 \\
7.47 \\
0.05 \\
0.51 \\
0.19 \\
1.77\end{array}$ & $\begin{array}{r}30.56 \\
19.14 \\
0.20 \\
0.00 \\
24.14 \\
0.03 \\
7.40 \\
0.07 \\
0.44 \\
0.14 \\
2.50\end{array}$ & $\begin{array}{r}30.84 \\
20.67 \\
0.22 \\
0.00 \\
18.00 \\
0.00 \\
4.33 \\
0.00 \\
0.51 \\
0.15 \\
2.82\end{array}$ & $\begin{array}{r}25.50 \\
21.06 \\
0.14 \\
0.04 \\
28.63 \\
0.02 \\
10.54 \\
0.10 \\
0.23 \\
0.03 \\
0.22\end{array}$ & $\begin{array}{r}26.43 \\
21.26 \\
0.10 \\
0.04 \\
26.81 \\
0.01 \\
10.10 \\
0.04 \\
0.38 \\
0.05 \\
0.21\end{array}$ & $\begin{array}{r}27.85 \\
20.54 \\
0.22 \\
0.00 \\
24.24 \\
0.02 \\
9.45 \\
0.07 \\
0.31 \\
0.03 \\
0.95\end{array}$ & $\begin{array}{r}28.54 \\
20.16 \\
0.31 \\
0.00 \\
28.09 \\
0.00 \\
9.17 \\
0.11 \\
0.38 \\
0.07 \\
1.25\end{array}$ & $\begin{array}{r}30.06 \\
22.91 \\
0.18 \\
0.02 \\
23.73 \\
0.02 \\
8.68 \\
0.05 \\
0.16 \\
0.06 \\
1.64\end{array}$ & $\begin{array}{r}31.73 \\
22.97 \\
0.44 \\
0.05 \\
20.26 \\
0.00 \\
7.44 \\
0.05 \\
0.27 \\
0.08 \\
2.27\end{array}$ & $\begin{array}{r}32.97 \\
22.39 \\
0.41 \\
0.00 \\
23.17 \\
0.00 \\
6.23 \\
0.09 \\
0.32 \\
0.10 \\
2.24\end{array}$ \\
\hline Total & 85.34 & 81.28 & 82.04 & 83.73 & 84.61 & 77.55 & 86.50 & 85.41 & 83.66 & 88.08 & 87.51 & 85.59 & 88.02 \\
\hline $\begin{array}{l}\text { Si apfu } \\
{ }^{\mathrm{N}} \mathrm{Al} \\
\mathrm{vl}^{\mathrm{N}} \mathrm{Al} \\
\mathrm{Ai} \\
\mathrm{Fe}^{\mathrm{z}^{2-}} \\
\mathrm{Mg} \\
\mathrm{Mn} \\
\mathrm{Ca} \\
\mathrm{Na} \\
\mathrm{K}\end{array}$ & $\begin{array}{l}2.86 \\
1.14 \\
1.28 \\
0.41 \\
2.34 \\
1.41 \\
0.01 \\
0.02 \\
0.01 \\
0.13\end{array}$ & $\begin{array}{l}3.12 \\
0.88 \\
1.52 \\
0.04 \\
2.52 \\
1.41 \\
0.00 \\
0.05 \\
0.02 \\
0.12\end{array}$ & $\begin{array}{l}3.21 \\
0.79 \\
1.63 \\
0.01 \\
2.47 \\
1.26 \\
0.00 \\
0.05 \\
0.04 \\
0.25\end{array}$ & $\begin{array}{l}3.23 \\
0.77 \\
1.68 \\
0.01 \\
2.40 \\
1.24 \\
0.00 \\
0.06 \\
0.04 \\
0.25\end{array}$ & $\begin{array}{l}3.32 \\
0.68 \\
1.77 \\
0.02 \\
2.19 \\
1.20 \\
0.00 \\
0.05 \\
0.03 \\
0.35\end{array}$ & $\begin{array}{l}3.52 \\
0.48 \\
2.30 \\
0.02 \\
1.72 \\
0.74 \\
0.00 \\
0.06 \\
0.03 \\
0.41\end{array}$ & $\begin{array}{l}2.77 \\
1.23 \\
1.47 \\
0.01 \\
2.60 \\
1.71 \\
0.00 \\
0.03 \\
0.01 \\
0.03\end{array}$ & $\begin{array}{l}2.87 \\
1.13 \\
1.59 \\
0.01 \\
2.44 \\
1.64 \\
0.00 \\
0.04 \\
0.01 \\
0.03\end{array}$ & $\begin{array}{l}3.05 \\
0.95 \\
1.70 \\
0.01 \\
2.22 \\
1.54 \\
0.00 \\
0.04 \\
0.00 \\
0.13\end{array}$ & $\begin{array}{l}3.04 \\
0.96 \\
1.57 \\
0.02 \\
2.50 \\
1.45 \\
0.01 \\
0.04 \\
0.01 \\
0.17\end{array}$ & $\begin{array}{l}3.11 \\
0.89 \\
1.91 \\
0.01 \\
2.06 \\
1.34 \\
0.00 \\
0.02 \\
0.01 \\
0.22\end{array}$ & $\begin{array}{l}3.30 \\
0.70 \\
2.11 \\
0.03 \\
1.76 \\
1.16 \\
0.00 \\
0.03 \\
0.02 \\
0.30\end{array}$ & $\begin{array}{l}3.37 \\
0.63 \\
2.07 \\
0.03 \\
1.98 \\
0.96 \\
0.00 \\
0.03 \\
0.02 \\
0.29\end{array}$ \\
\hline $\mathrm{Fe} /(\mathrm{Fe}+\mathrm{Mg})$ & 0.62 & 0.64 & 0.66 & 0.66 & 0.65 & 0.70 & 0.60 & 0.60 & 0.59 & 0.63 & 0.61 & 0.60 & 0.67 \\
\hline
\end{tabular}

The composition are recast in terms of a structural formula expressed as atoms per formula unit $(a p f u)$ calculated on the basis of $14(\mathrm{O}, \mathrm{OH})$.
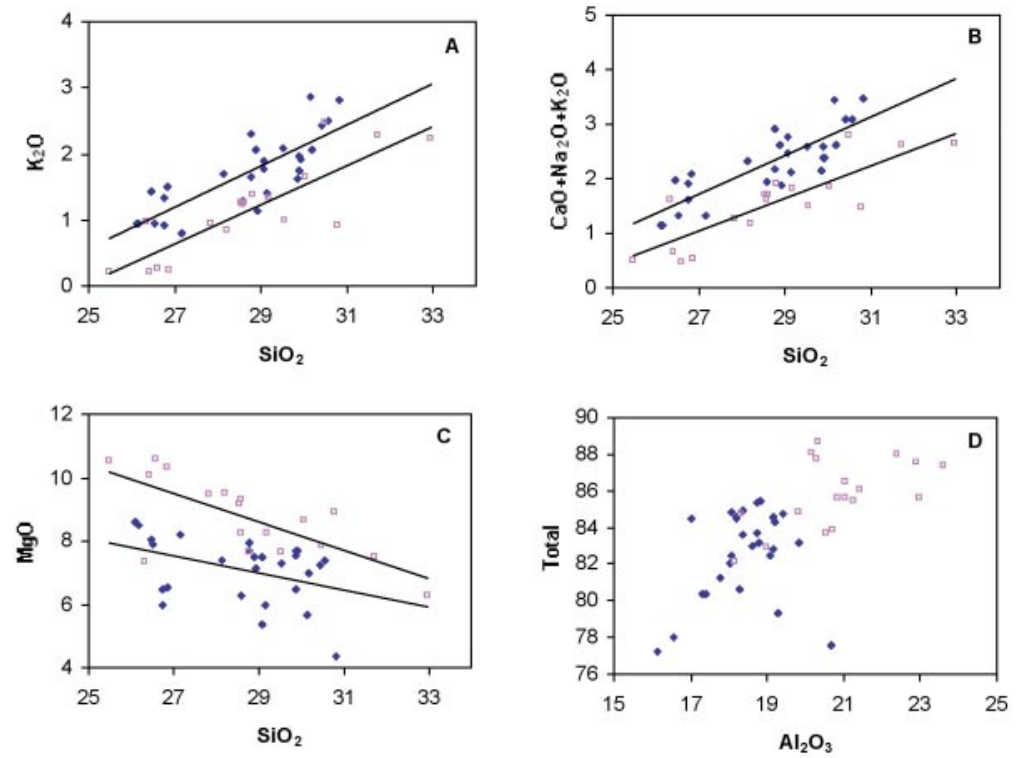

FIG. 5. Plots of the EMPA data of "vermiculitic phases". Full diamond: "vermiculite" parallel to the schistosity. Empty squares: "vermiculite" pseudomorphs. Oxide values are in wt.\%. 
increase of vermiculite layers in the mixed-layer structure is characterized by the increase in both $\mathrm{Si}$ and $\mathrm{K}+$ $\mathrm{Ca}$ contents, coupled with the parallel decrease in $\mathrm{Fe}+$ $\mathrm{Mg}$ content. Nevertheless, the $\mathrm{Fe} /(\mathrm{Fe}+\mathrm{Mg})$ values remain almost unchanged. Some differences with the EMPA data are evident, specially the lower Fe content and the scarcity or lack of Ti in the AEM analyses. These differences are related to the presence of the submicroscopic inclusions of $\mathrm{Fe}-\mathrm{Ti}$ oxide, as well as to the presence of Fe oxide alteration. As a consequence, the $\mathrm{Fe} /(\mathrm{Fe}+\mathrm{Mg})$ value decreases down to 0.4 .

Low-magnification TEM images from vermiculite pseudomorphs after garnet, coupled with AEM data, reveal intergrowths of different types of phyllosilicates, present as packets of very variable thickness (Fig. 10). These include vermiculite-, chlorite-, muscovite-, and thin packets of dioctahedral smectite. Vermiculite packets are of the order of 500-1000 A thick and, as revealed by the SAED patterns (Fig. 11A), show lattice-fringe images characterized by 10 A periodicity; locally, layers $14 \AA$ thick are present. Muscovite packets are generally coarser and show both 10 and $20 \AA$ periodicities, revealing the presence of a two-layer polytype (Fig. 11B). Chlorite packets, with 14 A periodicities, appear in most cases partially transformed to vermiculite; the transition occurs both along and across the layers (Fig. 12). In addition, thin layers of a dioctahedral smectite appear intergrown with the muscovite and vermiculite packets (Fig. 10). Smectite packets preferentially appear in the inner part of the vermiculite or muscovite packets. The smectite could be interpreted as formed during retrogression of the metamorphic phyllosilicates. Nevertheless, the observed textural relations rather suggest that the smectite packets represent relics of a previous phase, formed during retrogression of garnet, which could evolve toward vermiculite (or chlorite) and muscovite during a later prograde process.

Besides lattice-fringe images and SAED patterns, AEM data (Table 2) reveal the nature of the different phyllosilicates; compositions 9 and 10B have been recalculated on the basis of $11(\mathrm{O}, \mathrm{OH})$. Composition $10 \mathrm{~A}$ corresponds to muscovite that shows a near-ideal composition, with only $0.14 \mathrm{Fe} a p f u$. The relatively low $\mathrm{Si}$

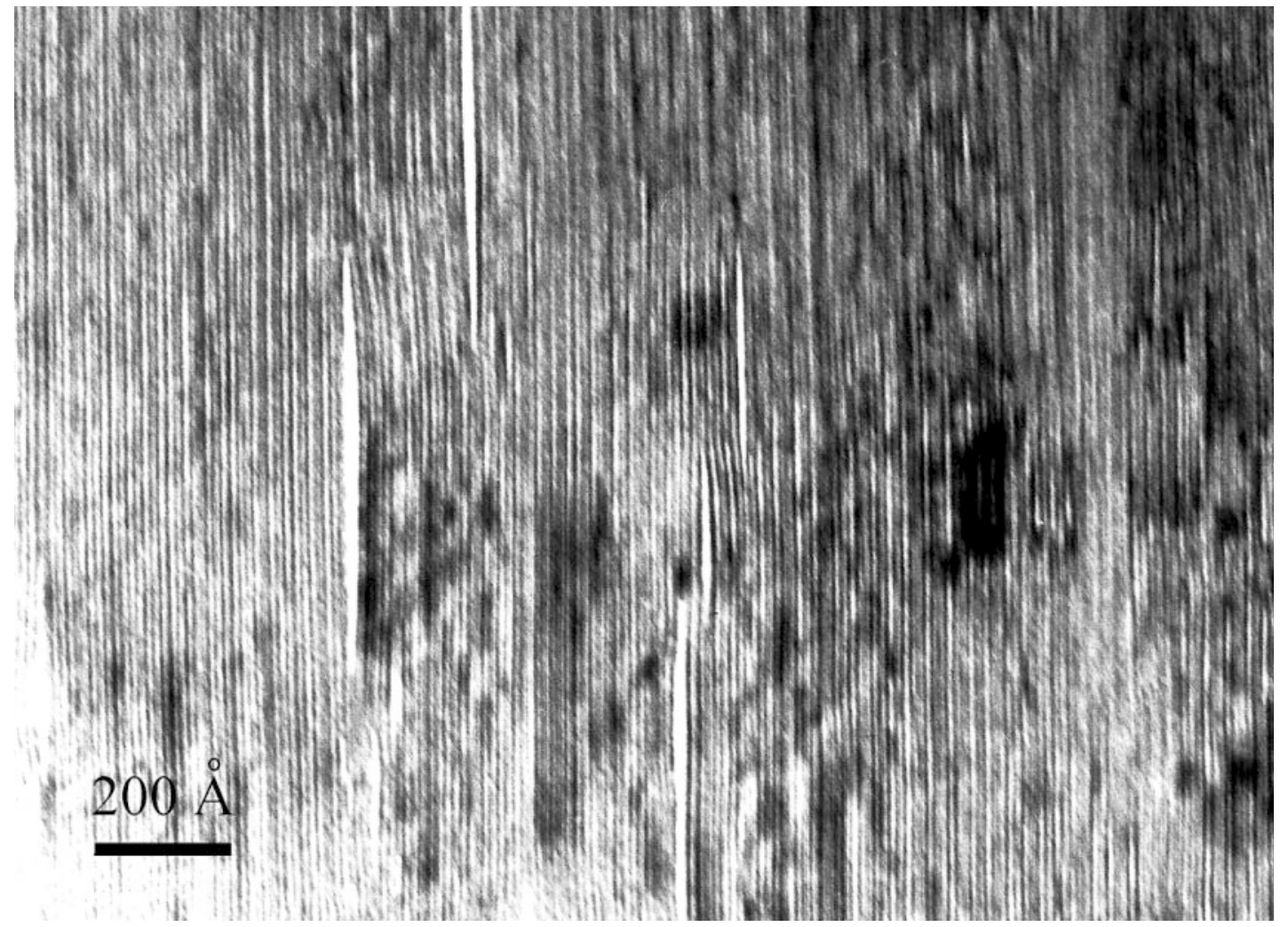

FIG. 6. Typical aspect of "vermiculitic" packets in "vermiculitic" grains parallel to the schistosity. 

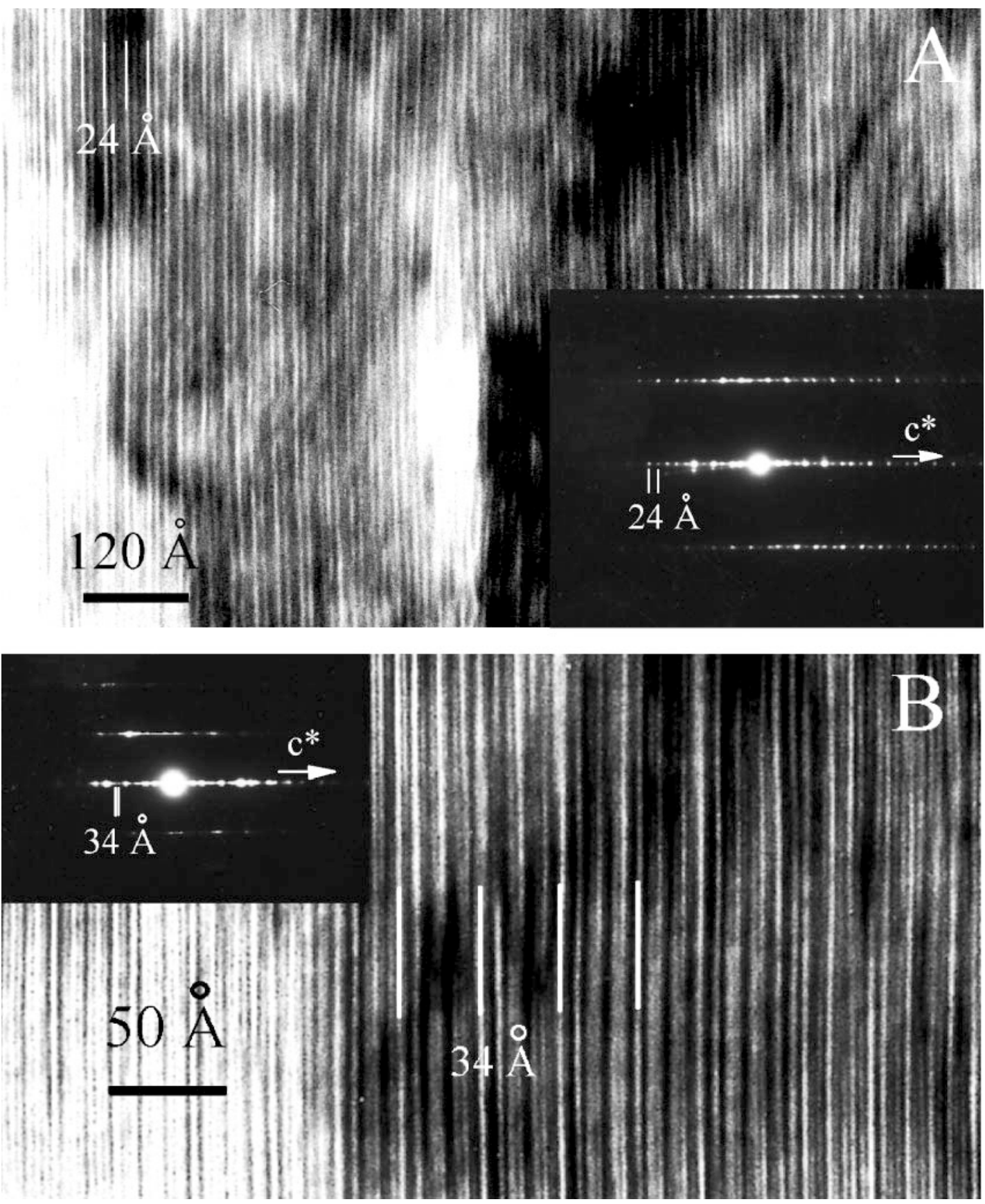

FIG. 7. Lattice-fringe images showing the most common sequences in "vermiculite" parallel to the schistosity. A. The 1:1 chlorite-vermiculite sequences with 24 A periodicity. The SAED patterns (inset) reveals the regularity of the interstratification. B. The chlorite-vermiculite sequences with 34 Å basal periodicity, also indicated by the SAED pattern (inset). 

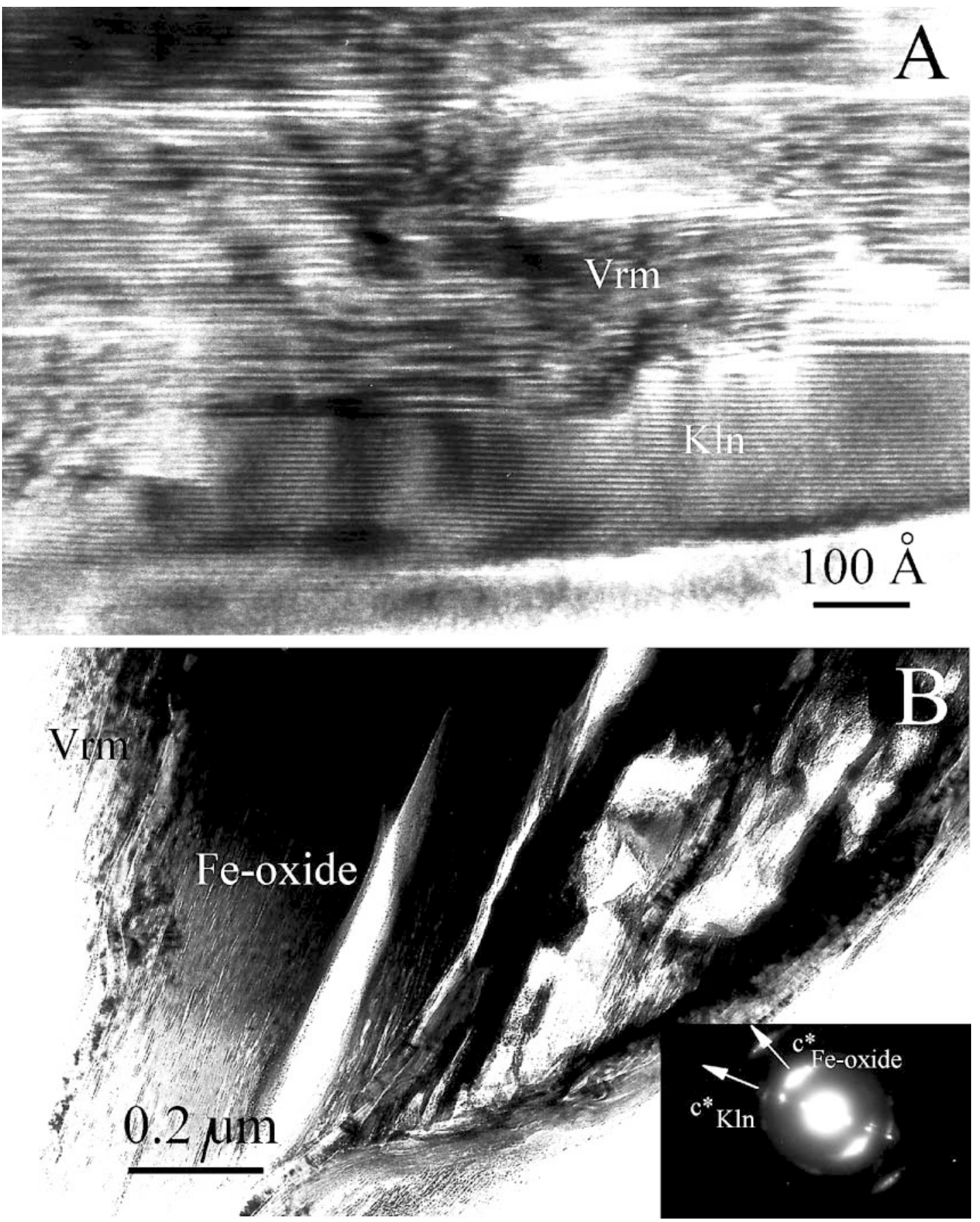

FIG. 8. TEM images showing the alteration products of "vermiculite" from the matrix. A. Kaolinite replacement of "vermiculite" at the external zone of a grain. B. Fe-oxide lens included in a "vermiculite" packet. The SAED pattern (inset) reveals the poor crystallinity of the Fe oxide intergrown with kaolinite. 
TABLE 2. REPRESENTATIVE AEM DATA FOR "VERMICULITIC PHASES" FROM THE MATRIX AND FROM PSEUDOMORPHS AFTER GARNET, MALÁGUIDE COMPLEX, SPAIN

\begin{tabular}{|c|c|c|c|c|c|c|c|c|c|c|c|c|c|c|}
\hline & \multicolumn{6}{|c|}{ Vermiculite parallel to the schistosity } & \multicolumn{8}{|c|}{ Pseudomorphs after garnet } \\
\hline & $\begin{array}{c}\text { ML } \\
(1: 1) \\
5\end{array}$ & $\begin{array}{c}\mathrm{ML} \\
(1: 1) \\
6 \mathrm{~A}\end{array}$ & $\begin{array}{l}\text { ML } \\
(1: 2) \\
\text { N.S. }\end{array}$ & $\begin{array}{c}\mathrm{ML} \\
(1: 2) \\
6 \mathrm{~B}\end{array}$ & $\begin{array}{l}\text { Vrm } \\
\text { N.S. }\end{array}$ & $\begin{array}{c}\text { Vrm } \\
7\end{array}$ & $\begin{array}{l}\text { Chl } \\
11\end{array}$ & $\begin{array}{c}\text { Vrm** } \\
10 \mathrm{~A}\end{array}$ & $\begin{array}{c}\text { Vrm } \\
11\end{array}$ & $\begin{array}{l}\text { Vrm } \\
\text { N.S. }\end{array}$ & $\begin{array}{l}\text { Vrm } \\
\text { N.S. }\end{array}$ & $\begin{array}{l}\text { Vrm } \\
\text { N.S. }\end{array}$ & $\begin{array}{c}\text { Ms } \\
10 \mathrm{~B}^{*}\end{array}$ & $\begin{array}{l}\mathrm{Sm} \\
9^{*}\end{array}$ \\
\hline$\%$ & 30.09 & 30.73 & 32.84 & 33.08 & 34.57 & 35.50 & 27.12 & 29.40 & 31.71 & 33.91 & 34.15 & 35.22 & 42.92 & 63.71 \\
\hline $\mathrm{Al}$ & 26.21 & 24.20 & 27.39 & 29.38 & 25.92 & 30.00 & 28.32 & 26.51 & 26.34 & 25.80 & 24.57 & 23.89 & 41.61 & 26.87 \\
\hline $\mathrm{Ti}$ & 0.00 & 0.00 & 0.00 & 0.25 & 0.00 & 0.00 & 0.00 & 0.00 & 0.00 & 0.00 & 0.00 & 0.00 & 0.00 & 0.00 \\
\hline $\mathrm{Fe}$ & 16.75 & 18.15 & 14.81 & 14.32 & 13.33 & 13.00 & 26.92 & 25.55 & 18.78 & 19.41 & 19.16 & 20.69 & 2.06 & 4.43 \\
\hline $\mathrm{Mg}$ & 25.49 & 24.94 & 23.91 & 20.25 & 13.95 & 19.00 & 16.83 & 14.70 & 20.49 & 17.69 & 19.66 & 17.00 & 0.00 & 3.88 \\
\hline $\mathrm{Mn}$ & 0.00 & 0.00 & 0.00 & 0.00 & 0.00 & 0.00 & 0.00 & 0.00 & 0.00 & 0.00 & 0.00 & 0.00 & 0.00 & 0.00 \\
\hline $\mathrm{Ca}$ & 0.49 & 0.73 & 0.05 & 0.25 & 0.74 & 0.75 & 0.00 & 0.48 & 0.49 & 1.47 & 0.74 & 1.72 & 0.00 & 0.00 \\
\hline $\mathrm{K}$ & 1.21 & 1.21 & 1.20 & 2.22 & 1.48 & 1.50 & 0.81 & 3.13 & 1.95 & 1.72 & 1.72 & 1.23 & 13.62 & 3.60 \\
\hline Si apfu & 2.95 & 3.05 & 3.15 & 3.15 & 3.29 & 3.31 & 2.70 & 2.93 & 3.08 & 3.26 & 3.28 & 3.37 & 3.01 & 3.94 \\
\hline & 1 & 0.95 & 0.85 & 0.85 & 0. & 0. & 1. & 1.07 & 0. & 0 & 0 & & 0.99 & 0.06 \\
\hline${ }^{{ }^{\mathrm{l}} \mathrm{Al}}$ & 1 & 1.44 & 1.78 & 1.92 & 1.7 & 2.11 & 1.50 & 1.57 & 1.64 & 1.7 & 1.64 & 1.66 & 1.93 & 1.60 \\
\hline $\mathrm{Ti}$ & 0.00 & 0.00 & 0.00 & 0.02 & 0.00 & 0.00 & 0.00 & 0.00 & 0.00 & 0.00 & 0.00 & 0.00 & 0.00 & 0.00 \\
\hline $\mathrm{Fe}^{2+}$ & 1.64 & 1.79 & 1.42 & 1.36 & 1.27 & 1.21 & 2.67 & 2.54 & 1.82 & 1.86 & 1.84 & 1.98 & 0.14 & 0.27 \\
\hline $\mathrm{Mg}$ & 2.50 & 2.46 & 2.30 & 1.93 & 2.28 & 1.77 & 1.67 & 1.47 & 1.99 & 1.7 & 1.89 & 1.63 & 0.00 & 0.24 \\
\hline $\mathrm{Mn}$ & 0.00 & 0.00 & 0.00 & 0.00 & 0.00 & 0.00 & 0.00 & 0.00 & 0.00 & 0.00 & 0.00 & 0.00 & 0.00 & 0.00 \\
\hline $\mathrm{Ca}$ & 0.05 & 0.07 & 0.00 & 0.02 & 0.07 & 0.07 & 0.00 & 0.05 & 0.05 & 0.14 & 0.07 & 0.17 & 0.00 & 0.00 \\
\hline $\mathrm{K}$ & 0.12 & 0.12 & 0.12 & 0.21 & 0.14 & 0.14 & 0.08 & 0.31 & 0.19 & 0.17 & 0.16 & 0.12 & 0.95 & 0.22 \\
\hline $\mathrm{Fe} /(\mathrm{Fe}+\mathrm{Mg})$ & 0.39 & 0.42 & 0.38 & 0.41 & 0.36 & 0.41 & 0.62 & 0.63 & 0.48 & 0.51 & 0.49 & 0.55 & -- & - \\
\hline
\end{tabular}

Numbers of the analytical datasets correspond to figures. N.S.: Not shown in the figures. * The composition are recast in terms of a structural formula expressed as atoms per formula unit (apfu) calculated on the basis of 11 $(\mathrm{O}, \mathrm{OH})$. ML: Mixed layers, Vrm: vermiculite, $\mathrm{Vrm}^{* *}$ : vermiculite containing scattered layers of chlorite, Chl: chlorite, Ms: muscovite, Sm: smectite.

content (3.1 apfu) suggests low-pressure conditions, according to Massone \& Schreyer (1987). Composition 9 corresponds to a dioctahedral smectite, montmorillonite, according to the classification by Newman \& Brown (1987). All other analytical results are recalculated on the basis of $14(\mathrm{O}, \mathrm{OH})$. Some of the compositions correspond to chlorite, whereas higher $\mathrm{Si}$ and $\mathrm{Ca}$ $+\mathrm{K}$ contents are characteristic of vermiculite. Vermiculite shows a range of chemical compositions, although Si contents $>3$ apfu are characteristic. Compared to the compositions of "vermiculite" parallel to the schistosity, "vermiculite" pseudomorphic after garnet show higher $\mathrm{Fe}$, leading to average $\mathrm{Fe} /(\mathrm{Fe}+\mathrm{Mg})$ value of 0.53 . In spite of the different sizes of the areas analyzed by EMPA and AEM, these data are very similar to those obtained by EMPA.

\section{DISCUSSION}

As noted in previous sections, vermiculitic phases are present in the sample studied both as a matrix constituent and as a pseudomorph after garnet. Thus, textural relations suggest that the genesis of "vermiculite" parallel to the schistosity was probably coeval to or earlier than the garnet, whereas the other population of "vermiculite" postdates garnet breakdown. On the basis of textural criteria, the possibility that "vermiculite" grains parallel to the schistosity represents re-equilibration of earlier biotite cannot be discarded. Nevertheless, this possibility seems unlikely, since in higher-grade rocks, biotite does not show signs of retrogression to vermiculitic phases (unpubl. data). Therefore, a retrograde origin for vermiculite in the matrix may be ruled out.

The presence of two stages of formation of "vermiculite" can also be evaluated on the basis of chemical, crystallochemical, and structural criteria, similar to those used for other phyllosilicates (mica and chlorite). In successive generations of a given phyllosilicate, textural differences are seldom accompanied by differences in chemical composition, which are more evident in ferromagnesian phases, such as chlorite (e.g., Curtis et al. 1985, Ruiz Cruz 1997). These differences mainly affect the $\mathrm{Fe} /(\mathrm{Fe}+\mathrm{Mg})$ value, and occasionally the $\mathrm{Fe}^{3+}: \mathrm{Fe}^{2+}$ ratio, and seem reflected in the optical properties (Deer et al. 1976). As shown before, electron-microprobe data reveal systematic chemical differences between the two populations of vermiculite, which mainly affect the Al, $\mathrm{Mg}$, Ti and alkalis + alkaline-earth contents. The high Ti content in some "vermiculite" grains parallel to the schistosity, which is similar to that present in titaniferous biotite from metamorphic rocks (Guidotti 1984), would seem to suggest a retrogression from pre-existing biotite. Nevertheless, the TEM-AEM data indicate that this "vermiculite" does not contain Ti, this element being present instead as submicroscopic inclusions of $\mathrm{Fe}-\mathrm{Ti}$ oxide.

The TEM-AEM study carried out on "vermiculite" grains belonging to the main schistosity reveals lack of topotactic relations between "vermiculite" and Fe and 


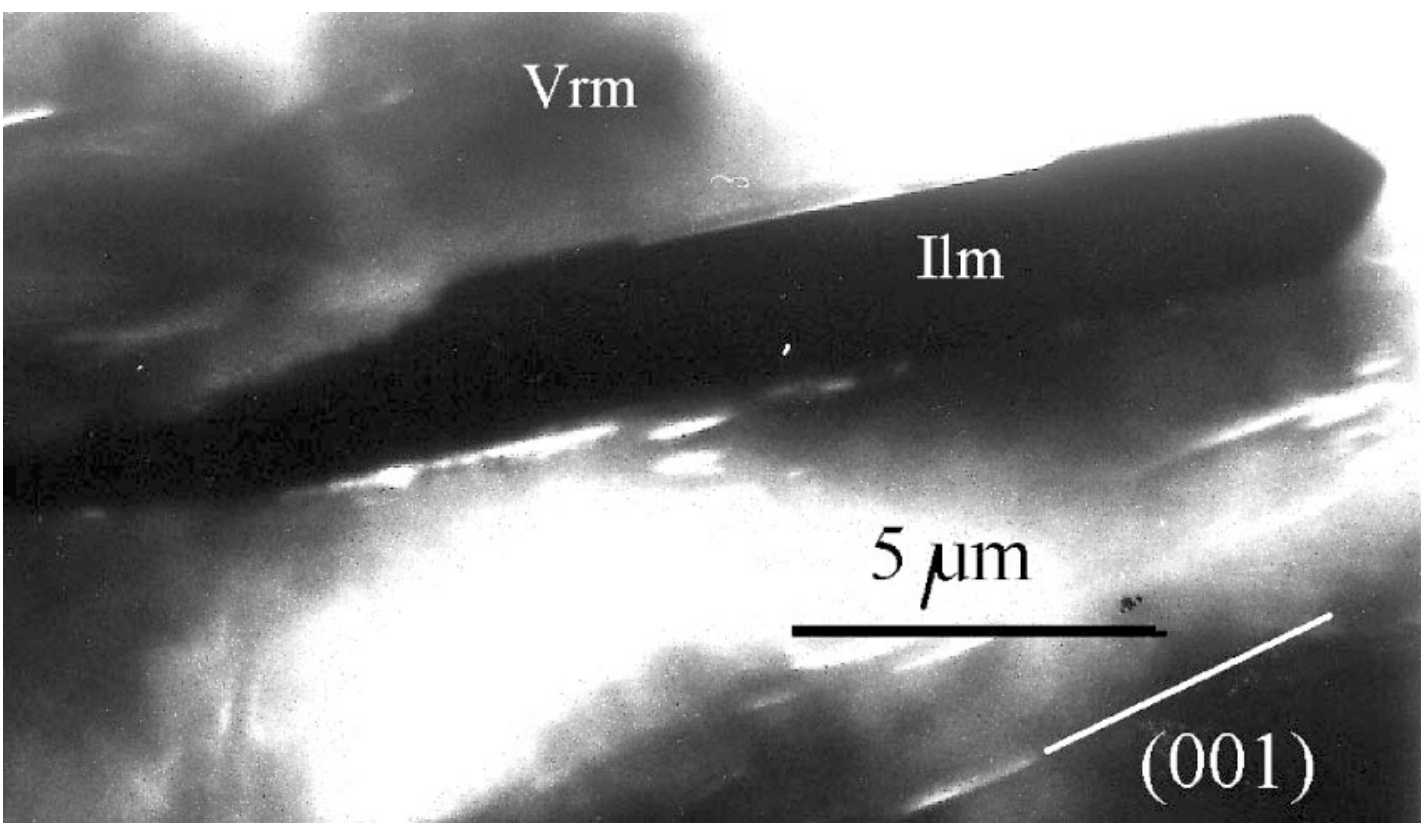

FIG. 9. Low-magnification TEM image of an ilmenite (Ilm) inclusion in "vermiculite" (Vrm) from matrix. White line marks the (001) planes of the host "vermiculite".
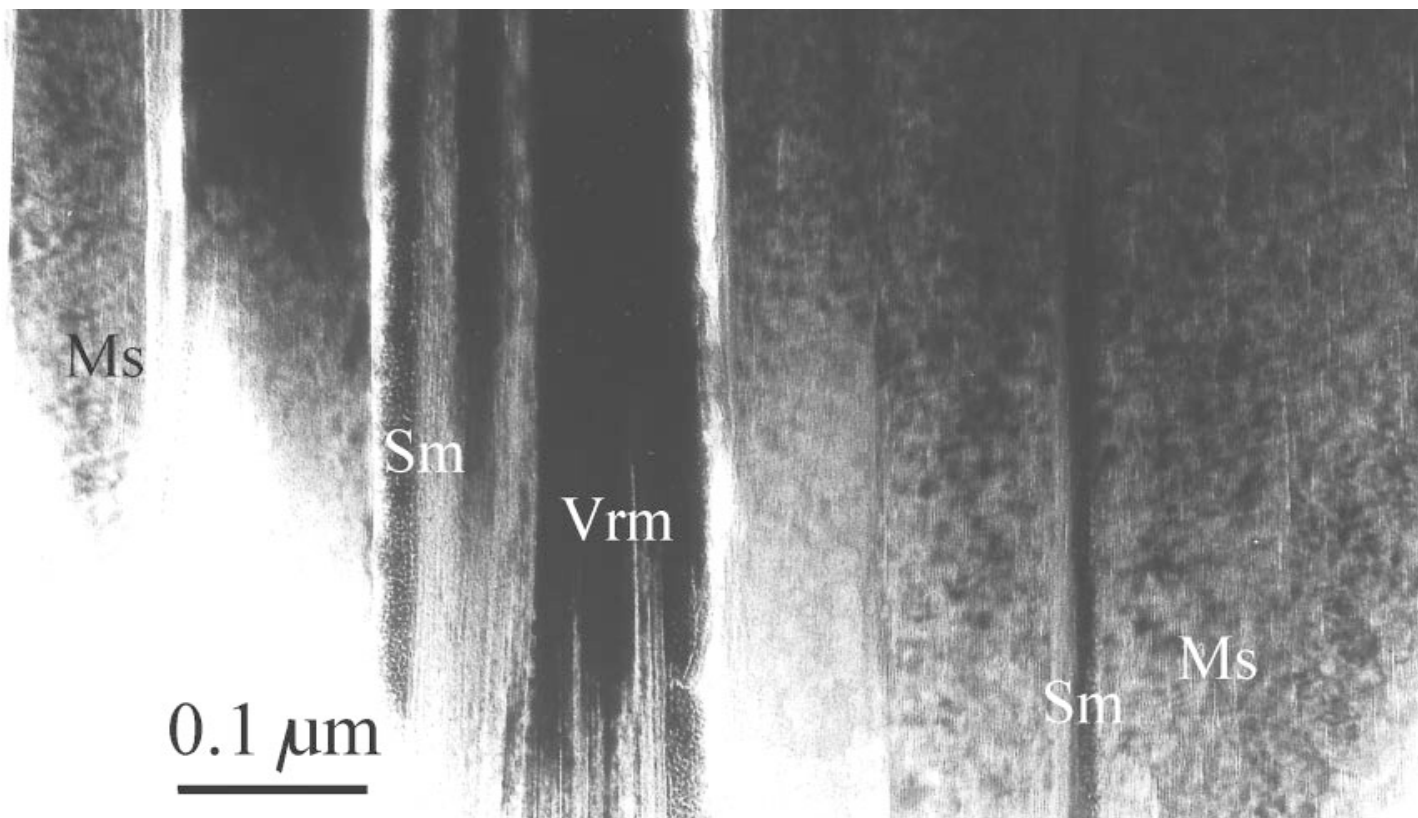

FIG. 10. Low-magnification TEM image of "vermiculite" pseudomorph after garnet. These grains appear to consist of parallel packets of muscovite (Ms), vermiculite + chlorite (Vrm), and an aluminous smectite (Sm). 

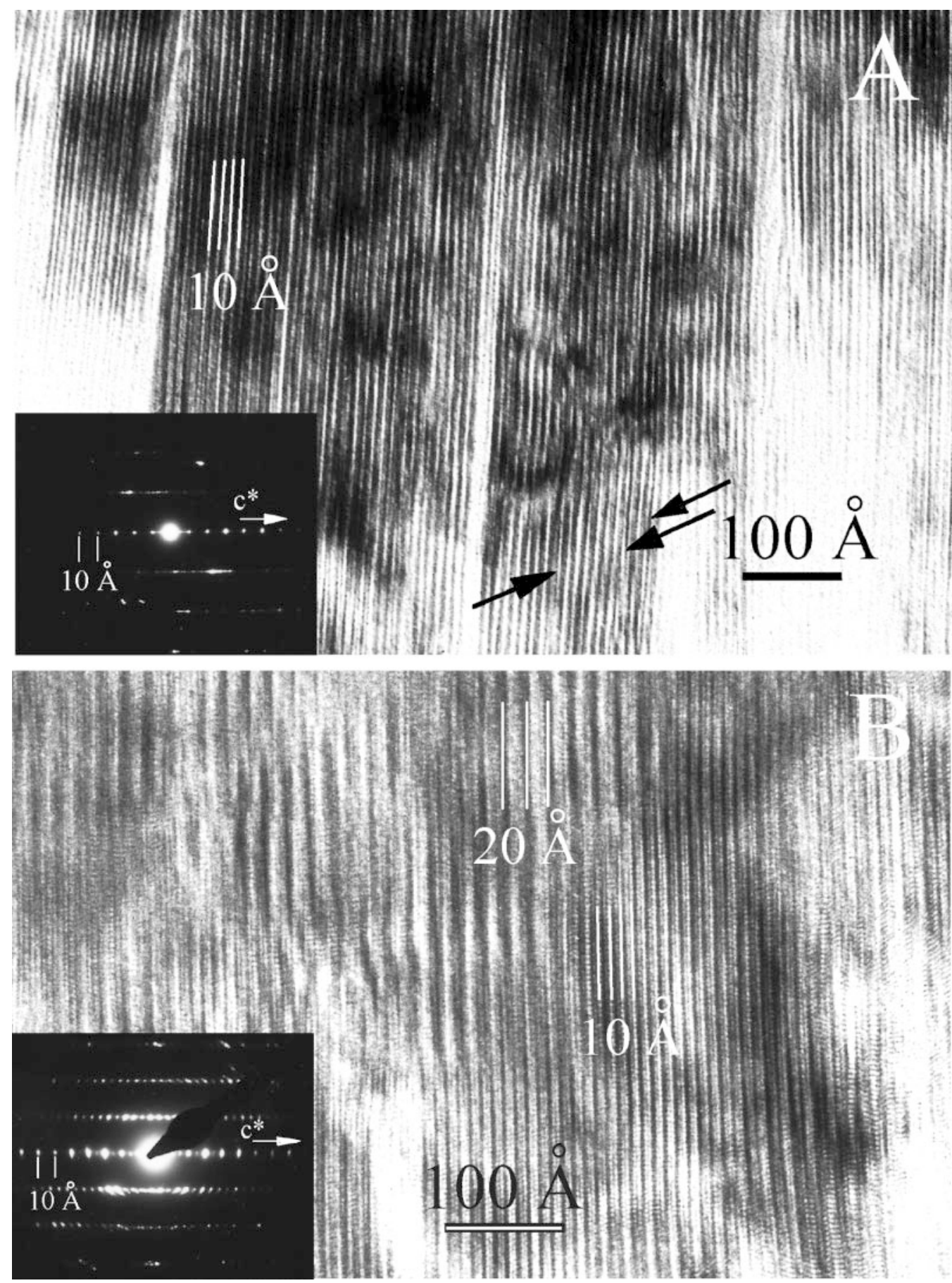

FIG. 11. A. Lattice-fringe image of vermiculite packets from garnet replacements. These packets show a predominant regular 10 -A periodicity, although some thinner fringes (arrows), probably corresponding to brucite-like layers, are occasionally present. The SAED pattern (inset) shows the dominant 10-Å spacing. B. Lattice-fringe image of muscovite coexisting with vermiculite in the stacks that replace garnet. The SAED pattern (inset) as well as the lattice-fringe image indicate a two-layer polytype. 


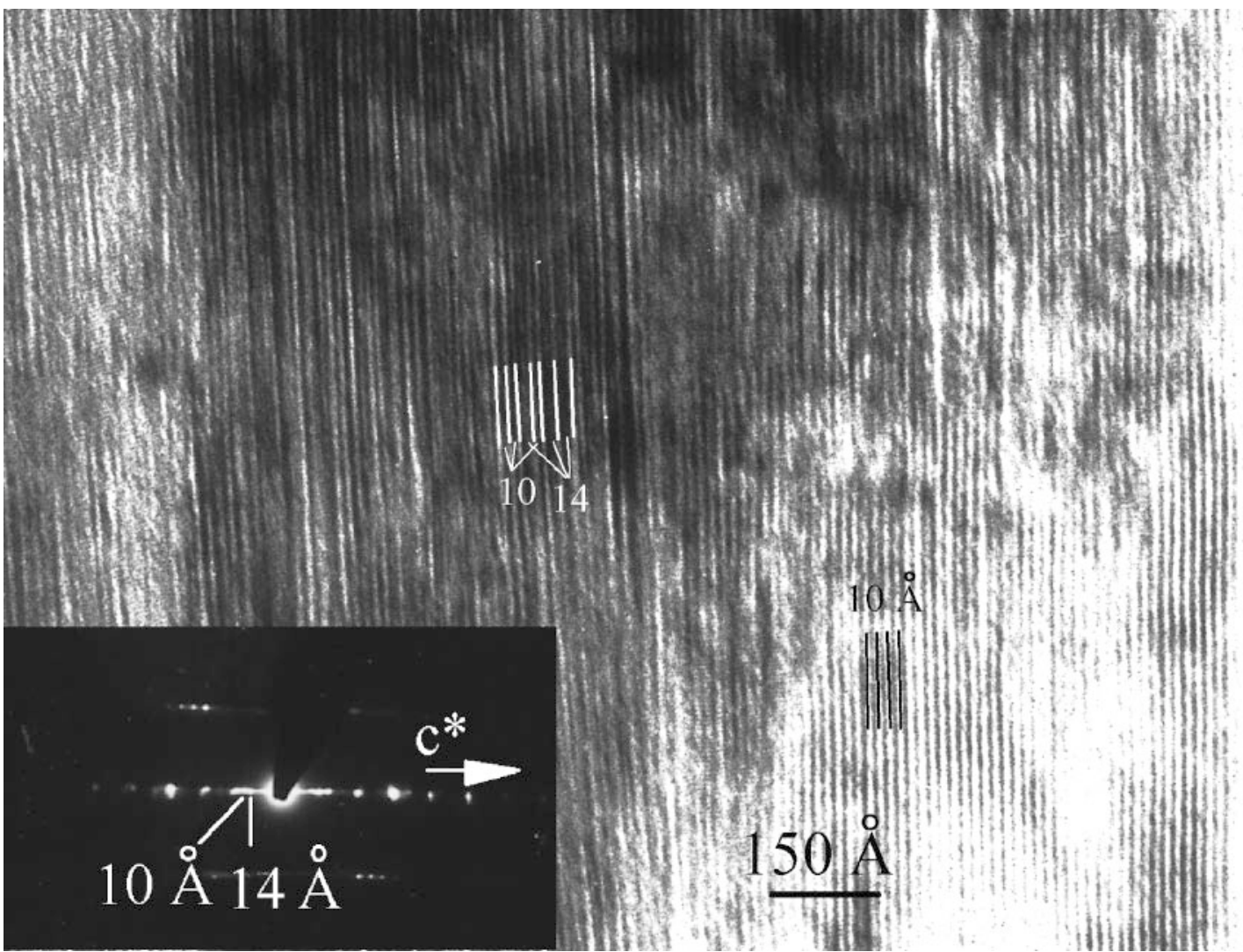

FIG. 12. This image illustrates the incomplete transformation of chlorite into vermiculite. The chlorite packet contains numerous interstratified 10-A layers. The SAED pattern (inset) show reflections of both chlorite (14 $)$ and vermiculite $(10 \AA)$.

Fe-Ti oxides, indicating that such oxides are not due to exsolution but rather are primary inclusions. Presence of oriented $\mathrm{Ti}-\mathrm{Fe}$ oxide blebs would be evidence of a retrograde metamorphic process. On the other hand, the presence of disoriented inclusions (relics) within phyllosilicates can be interpreted as evidence for a later crystallization.

The AEM data also reveal important differences in $\mathrm{Fe} /(\mathrm{Fe}+\mathrm{Mg})$ between the two texturally different types of "vermiculite", which were not detected from the EMPA analyses. Differences between EMPA and AEM results are related to the presence of small inclusions of both $\mathrm{Fe}$ and $\mathrm{Fe}-\mathrm{Ti}$ oxides, which adversely affect the accuracy of EMPA chemical data.

Structural criteria are seldom useful tools to differentiate between phyllosilicates of different origins. Thus, the exact determination of both the mica and chlorite polytypes and of their crystallinity indices was widely used to differentiate phases formed at different diagenetic-to-metamorphic conditions (e.g., Frey 1987, Frey \& Robinson 1999). In the schists described here, the first generation of "vermiculite" mainly consists of regular chlorite-vermiculite interstratifications with a ratio $1: 1$ and $1: 2$, the latter being dominant. Interstratified chlorite-vermiculite structures richer in chlorite $(2: 1)$ have been described in the lower-grade Paleozoic rocks and interpreted as formed during the prograde Alpine episode of metamorphism. The findings of the present study confirm the increase of vermiculite layers in the interstratified structure as metamorphic grade increases. On the contrary, "vermiculite" pseudomorphs consist of submicroscopic intergrowths of several types of phases (muscovite, chlorite, vermiculite, and dioctahedral smectite), similar to those described by Mellini et al. (1991) for the Nevado-Filabride micaschists. The "vermiculite" grains (muscovite + vermiculite + chlorite) pseudomorphs after garnet probably formed from smectite during a later thermal event. Thus, the structural characteristics of both populations of "vermiculite" are also different, and confirm their formation during different episodes of metamorphism. 


\section{Concluding Remarks}

Textural, chemical and crystallochemical criteria were used to characterize two different populations of metamorphic "vermiculite" from schists of the Betic Cordillera. The first one appears as grains belonging to the main schistosity and shows optical properties similar to biotite. Structurally, this "vermiculite" grains consists of $1: 1$ and 1:2 chlorite-vermiculite mixed-layers, and contains numerous unoriented inclusions of Fe and $\mathrm{Fe}-\mathrm{Ti}$ oxides. For the first population, the AEM data are characterized by $\mathrm{Fe} /(\mathrm{Fe}+\mathrm{Mg})$ values on the order of 0.39 . The second population of "vermiculite" forms a pseudomorph after almandine and consists of complexly intergrown grains containing muscovite, chlorite, vermiculite, and a dioctahedral smectite. The AEM data for the vermiculite pseudomorphs after garnet are characterized by $\mathrm{Fe} /(\mathrm{Fe}+\mathrm{Mg})$ values on the order of 0.55 .

Taking into consideration all the proposed textural, chemical and structural data, it seems evident that "vermiculite" grains belonging to the main schistosity and the ones that replace garnet formed during different stages of metamorphism. The first growth of "vermiculite" occurred during the main stage of mineral growth of the Alpine metamorphism (pre-Miocene), the precursor phase being probably chlorite, as observed in lowergrade Paleozoic rocks. On the other hand, this type of "vermiculite" appears retrograded to a kaolinite-like phase and Fe oxide. The metamorphic assemblage (including andalusite, garnet and staurolite) suggests that temperature was probably on the order of $500^{\circ} \mathrm{C}$. On the contrary, retrogression of almandine, probably to an aluminous smectite, and later formation of the present assemblage of phyllosilicates may be related to latestage metamorphic reactions occurring during relaxation and uplift of this terrane. The "vermiculite" grains pseudomorphic after garnet are probably coeval with vermiculite formation in metamorphosed dykes cutting across the lower part of the Paleozoic sequence, which occurred at a temperature below $400^{\circ} \mathrm{C}$ (Ruiz Cruz \& Novak 2003).

\section{ACKNOWLEDGEMENTS}

The author is grateful to A. Gómez and M.M. Abad for help in obtaining the TEM-AEM data. This study has received financial support from the Project BTE2000-1150 (Ministerio de Educación y Cultura) and from the Research Group RNM-199. Thanks are also due to two anonymous referees and to Robert F. Martin for very useful comments received as a result of the review process.

\section{REFERENCES}

AZAÑóN, J.M. (1994): Metamorfismo de alta presión-baja temperatura, baja presión-alta temperatura y tectónica del
Complejo Alpujárride (Cordilleras Bético-Rifeñas). Tesis. Universidad de Granada, Granada, Spain.

García-DueÑas, V. \& GofFé, B. (1998): Exhumation of high-pressure metapelites and coeval crustal extension in the Alpujarride complex (Betic Cordillera). Tectonophysics 285, 231-252.

BAILEY, S.W. (1980): Structures of Layer Silicates. In Crystal Structures of Clay Minerals and their X-Ray Identification (G.W. Brindley \& G. Brown, eds.). The Mineralogical Society, London, U.K. (1-123).

BalanYÁ, J.C., GarCíA-DueÑas, V. \& AZAÑón, J.M. (1997): Alternating contractional and extensional events in the Alpujárride nappes of the Alboran domain (Betics, Gibraltar Arc). Tectonics 16, 226-238.

BANFIELD, J.F. \& MURAKAMI, T. (1988): Atomic-resolution transmission electron microscope evidence for the mechanism by which chlorite weathers to $1: 1$ semi-regular chlorite-vermiculite. Am. Mineral. 83, 348-357.

BEAUFORT, D. (1987): Interstratified chlorite-smectite ("metamorphic vermiculite") in the upper Precambrian greywackes of Rouez, southern France. Proc. Int. Clay Conf. (Denver, 1985) (L.G. Schultz, H. Van Olphen \& F.A. Mumpton, eds.), 59-65.

BRown, E.H. (1967): The greenschist facies in part of eastern Otago, New Zealand. Contrib. Mineral. Petrol. 14, 259 292.

BRown, G. \& BRINDLEY, G.W. (1980): X-ray procedures for clay mineral identification. In Crystal Structures of Clay Minerals and their X-Ray Identification (G.W. Brindley \& G. Brown, eds.). The Mineralogical Society, London, U.K. (305-360).

Curtis, C.D., Hughes, C.R., Whiteman, J.A. \& White, C.K. (1985): Compositional variations within some sedimentary chlorites and some comments on their origin. Mineral. Mag. 49, 375-386.

DeER, W.A., Howie, R.A. \& Zussman, J. (1976): Rock-Forming Minerals. 2. Sheet Silicates. Longman, Green \& Co., London, U.K.

Francescelli, M., Mellini, M., Memmi, I. \& Ricci, C.A. (1986): Fine-scale chlorite-muscovite association in lowgrade metapelites from Nurra (NW Sardinia), and the possible misidentification of metamorphic vermiculite. Contrib. Mineral. Petrol. 93, 137-143.

FreY, M. (1987): Very low-grade metamorphism of clastic sedimentary rocks. In Low-Temperature Metamorphism (M. Frey, ed.). Blackie, Glasgow, U.K. (9-58).

\& RoBInson, D. (1999): Low-Grade Metamorphism. Blackwell Science, Oxford, U.K.

GuidotTI, C.V. (1984): Micas in metamorphic rocks. In Micas (S.W. Bailey, ed.). Rev. Mineral. 13, 357-467. 
JOHNSON, L.J. (1964): Occurrence of regularly interstratified chlorite-vermiculite as a weathering product of chlorite in a soil. Am. Mineral. 49, 556-572.

KERRICK, D.M. \& COTTON, W.R. (1971): Stability reactions of jadeite pyroxene in Franciscan metagreywackes near San Jose, California. Am. J. Sci. 271, 350-369.

Lorimer, G.W. \& ClifF, G. (1976): Analytical electron microscopy of minerals. In Electron Microscopy in Mineralogy (H.R. Wenk, ed.). Springer-Verlag, New York, N.Y. (506-519).

MäKel, G.H. (1985): The geology of the Maláguide Complex and its bearing on the geodynamic evolution of the BeticRif orogen (southern Spain and northern Morocco). GUA Papers of Geol. 22.

Maresch, W.V., Massone, H.-J. \& CZANK, M. (1985): Ordered and disordered chlorite-biotite interstratifications as alteration products of chlorite. Neues Jahrb. Mineral., Abh. 152, 79-100.

Massone, H.-J. \& SChreyer, W. (1987): Phengite geobarometry based on the limiting assemblage with K-feldspar, phlogopite, and quartz. Contrib. Mineral. Petrol. 96, 212224.

Mellini, M., Nieto, F., Alvarez, F. \& Gómez-Pugnaire, M.T. (1991): Mica-chlorite intermixing and altered chlorite from the Nevado-Filábride micaschists, southern Spain. Eur. J. Mineral. 3, 27-38.

Murakami, T., Isobe, H., Sato, T. \& Ohnuki, T. (1996): Weathering of chlorite in a quartz-chlorite schist. I. Mineralogical and chemical changes. Clays Clay Minerals 44, 244-256.

Newman, A.C.D. \& Brown, G. (1987): The chemical constitution of clays. In Chemistry of Clays and Clay Minerals (A.C.D. Newman, ed.). The Mineralogical Society, London, U.K. (1-128).

Proust, D. (1982): Supergene alteration of metamorphic chlorite in an amphibolite from Massif Central, France. Clay Minerals 17, 159-173.

Eymery, J.P. \& BEAUfort, D. (1986): Supergene vermiculitization of a magnesian chlorite: iron and magnesium removal process. Clays Clay Minerals 34, 572-580.
Puga, E., Díaz De Federico, A. \& Nieto, J.M. (2002): Tectonostratigraphic subdivision and petrological characterisation of the deepest complexes of the Betic zone: a review. Geodin. Acta 15, 23-43.

Nieto, J.M. \& Díaz De Federico, A. (2000): Contrasting P-T path in eclogites of the Betic Ophiolitic Association, Mulhacén Complex, southeastern Spain. Can. Mineral. 38, 1137-1161.

REYNOLDS, R.C., JR. (1988): Mixed-layer chlorite minerals. In Hydrous Phyllosilicates (Exclusive of Micas) (S.W. Bailey ed.). Rev. Mineral. 19, 601-629.

RUIZ CRUZ, M.D. (1997): Very low-grade chlorite with anomalous chemistry and optical properties from the Maláguide Complex, Betic Cordilleras, Spain. Can. Mineral. 35, 923935.

(1999): New data for metamorphic vermiculite. Eur. J. Mineral. 11, 533-548.

(2001): Mixed-layer mica-chlorite in very lowgrade metaclastites from the Maláguide Complex (Betic Cordilleras, Spain). Clay Minerals 36, 307-324.

Nieto, J.M., Puga, E. \& Díaz De Federico, A. (2003): Metamorfismo de diques máficos en la zona de Málaga. Bol. Soc. Esp. Miner. 26-A, 157-158.

\& NovaK, J. (2003): Metamorphic chlorite and "vermiculitic" phases in mafic dikes from the Maláguide Complex (Betic Cordillera, Spain). Eur. J. Mineral. 15, 6780.

\& RodríGueZ JimÉNEZ, P. (2002): Correlation between crystallochemical parameters of phyllosilicates and mineral facies in very low-grade metasediments of the Betic Cordillera (Spain): a synthesis. Clay Minerals 37, 169-185.

Velde, B. (1978): High temperature or metamorphic vermiculites. Contrib. Mineral. Petrol. 66, 319-323.

Received August 22, 2003, revised manuscript accepted November 3, 2003. 